Sakarya University Journal of Education, 5/3 (Aralik /December 2015) ss.172-173.

DOI: http://dx.doi.org/10.19126/suje.11270

\title{
Kitap İncelemesi
}

Eröz-Tuğa, BETiL (ed.) (2015). Theoretical Considerations in Language Education: Implications for English Language Teaching. Ankara: Nüans Publishing.

The dichotomy of theory and practice has long been the focal point in the realm of English Language Teaching (ELT). It is a widely known fact that it is not possible to consider these two as separate dimensions; without theory practice cannot be based on a strong infrastructure, and likewise, without practice theory becomes fruitless. However, what matters here is the need for a sheer balance between the two. In order to ensure this balance, professionals teaching English as a second or foreign language should be well aware of the theoretical background of the existing teaching practices. Practices can be deemed as the intended product of the theories. In other words, the applied dimension is yielded by the framework drawn by the theories. Therefore, they inevitably complement one another and should go hand in hand so as to achieve effective language teaching.

Theoretical Considerations in Language Education: Implications for English Language Teaching is a recent book that aims to provide a comprehensive theoretical framework of ELT with reference to implications for practice. Its target readership consists of ELT researchers and practitioners. The book has been written with the contribution of thirteen ELT researchers. Of 171 pages, the book covers four sections and thirteen chapters. The $10^{\text {th }}$ chapter of the book is written by the editor herself. Each section focuses on a specific field of social sciences, and each included chapter introduces a particular theory from that field extensively. The theories are first covered technically and then handled within the context of their implications for the potential applications in the field of English Language Teaching.
Section 1 is composed of 5 chapters and focuses on theories from psychology. Behaviorism and its implications for ELT constitute the topic of Chapter 1; and Piaget's Theory of Cognitive Development is covered in Chapter 2. The remaining two chapters touch on the social aspect of psychology. Chapter 3 covers Vygotsky's Sociocultural Theory, and Chapter 4 discusses Bandura's Social Learning Theory under the framework of their contributions to language teaching. The $5^{\text {th }}$ and last chapter of this section concentrates on Kelly's Personal Construct Psychology with reference to its implications for ELT.

Composed of four chapters, Section 2 is devoted to four theories from linguistics and sociolinguistics. Chapter 6 covers Chomsky's Theory of Universal Grammar and its implications while the following three chapters deal with theories within the borders of sociolinguistics. Chapter 7 is on Politeness Theory to the advent of which scholars like Goffman, Lakoff, Brown and Levinson, and Watts contributed. Chapter 8 focuses on Giles' Accommodation Theory and its implications for language teaching; and Chapter 9 is devoted to the link between Schumann's Acculturation Model and language teaching.

Section 3 consists of three chapters and discusses theories from anthropology and sociology. Chapter 10 is on the Theory of Symbolic Interactionism while Chapter 11 concentrates on Structural Functionalism and Chapter 12 investigates the Context of Situation Theory within the context of implications for language education. 
As for the last part of the book, Section 4 is composed of one chapter and focuses on Educational Philosophy. Chapter 13 tries to establish a link between the recently popular Theory of Critical Pedagogy and English language teaching practices.

Theoretical Considerations in Language Education: Implications for English Language Teaching possesses many strong sides. First of all, it provides a detailed account of major theories from linguistics and social sciences that have somehow contributed to the formation of language teaching theories. Therefore, the readers are allowed the chance to clearly observe the bridge between the branch of ELT and other related fields. The book also enables the readers to see the practical implications of these framework theories for the language classroom applications. This applied dimension is consolidated in almost each chapter through practical examples or sample activities and tasks. In addition, the to-the-point suggestions put forward at the end of the chapters are of high importance in that they directly address English language teachers to help them improve their way of teaching and achieve professional development.

Alongside the rich content and proper organization covered in the book, one possible criticism that can be addressed to the writers is the poor use of visuals in some chapters. Some of the visuals are not even legible enough. More and better visuals should have been used throughout the book so that the high-level function of visual aids in better comprehension and retention could have been employed. Notwithstanding this justifiable weak point, the strong plus points of the book render it a really useful and valuable resource for ELT researchers and practitioners. In a nutshell, the effort exerted by the editor and the authors of the chapters is worthy of mention and the produced work can certainly be considered among the recent must-read resources in the realm of language education.

İsmail YAMAN

Ondokuz Mayıs University

ELT Department

ismail.yaman@omu.edu.tr 